\title{
Process optimization for the production of ready-to-cook carrot halwa
}

\author{
Arvind, Pavan Choudhary, Shikha Pandhi, Dinesh Chandra Rai and Veena Paul
}

Received: 10 June 2020 / Accepted: 19 June 2020 / Published online: 10 September 2020

(C) Indian Dairy Association (India) 2020

\begin{abstract}
Increasing prevalence of nuclear family among the population as well as changing lifestyles have subjected consumers towards the adoption of instant food at the global level. Increasing popularity of ready-to-cook (RTC) foods amongst the consumers owing to convenience in their preparation, handling as well as their longer shelf life had encouraged the development of a variety of instant foods by various food processors. The term 'ready-to-cook' refers to simple, quick, and convenient food, which is easy and quicker to cook apart from being hygienic and free from contamination. The present study aims at the optimization of the recipe for the development of ready-to-cook carrot halwa based on color, texture, and sensory characteristics such as appearance, odor, taste, and overall acceptability. The sample $\left(\mathrm{H}_{4}\right)$ with desirable red color, best organoleptic properties, and least hardness was selected for the proximate analysis.
\end{abstract}

Keywords: Carrot halwa, Convenience, Instant, Ready-tocook

\section{Introduction}

Escalating affluence and changing lifestyles as a function of accelerating technology has become one of the most pervading trends in today's scenario (Mansoor et al. 2013). Fast-paced life

\footnotetext{
Department of Dairy Science and Food Technology

Institute of Agricultural Sciences

Banaras Hindu University

Varanasi-221 005, Uttar Pradesh, India

Arvind $(\bowtie)$

Department of Dairy Science and Food Technology

Institute of Agricultural Sciences

Banaras Hindu University

Varanasi-221 005, Uttar Pradesh, India

Phone:+91-9793583702

Email: arvind00000@gmail.com
}

and changing consumer needs have shown a paradigm shift towards processed foods that are easy and fast to cook. Readyto-cook products are one of the modern alternative solutions to these growing needs to ease the process of cooking (Munjal and Noida, 2019). Ready-to-cook foods are convenience foods that require less time and energy for the final food preparation. Indian traditional foods symbolize the wealth of cultural heritage that is gaining a lot of popularity in the world. Carrot halwa is also one amongst those traditional Indian sweetmeats that are highly relished in northern and western parts of India. It is a dense source of nutrients and calories generally prepared by cooking carrot shreds with milk and sugar in moderate frying oil and added with grated khoa. Carrot halwa forms an essential part of festivals, marriages, feasts, religious functions as well as of daily menus. But its preparation takes several hours depending on the number of raw materials used that makes the whole process is laborious and cumbersome.

It is preferred to make during winters eason due to availability of raw material at a reasonable price (Mathpal et al. 2017). Advancement of technological interventions has created an opportunity to enhance the availability of seasonal commodities round the year. Ready-to-cook food products are one such intervention to provide food formulations that are associated with constraints of seasonal availability with prolonged shelf life. Dehydration of fruits and vegetables is an efficient method for extending the shelf life by evaporating water while preserving the taste. Dehydration reduces the weight and space required to store and transports the products that remain stable in ordinary storage conditions.

The present study aims at optimization of the process for the development of ready-to-cook carrot halwa using blanched dried carrot shreds with different combinations of khoa powder and sugar. The study was based on optimization of parameters like rehydration time, rehydration ratio, volume expansion, density, and textural properties of dried carrot shreds for the production of carrot halwa and then the optimized blanched dried carrot shreds were mixed with a different amount of the khoa powder and sugar. 


\section{Materials and Methods}

Carrots, khoa, and sugar powder was purchased from the local market of Varanasi. All chemicals used in this study were of analytical grade and procured from Hi-Media Laboratories Pvt. Ltd., Mumbai, India; Fisher Scientific, Mumbai, India; Merck Specialties Pvt. Ltd., Mumbai, India.

\section{Optimization of blanched carrot shreds}

Carrot shreds were blanched for different time intervals as a pretreatment before dehydration with sugar and potassium metabisulphite (KMS). The experimental design for the blanching of the carrot shreds has been shown in Table 1. Six samples were obtained by subjecting carrot shreds to six different blanching times. The process for the blanching and drying of the carrot shreds has been described in Figure 1. The six samples thus obtained were optimized based on five different parameters such as:

\section{Bulk density $\left(\rho_{B}\right)$}

Bulk density is defined as the ratio of mass per unit volume. It is an important physical property that reveals the extent of porosity in a given sample. It is generally given by

Density $=\frac{\text { mass }}{\text { volume }}$

Higher bulk density corresponds to less number of pores. Lower bulk density corresponds to a more porous structure that indicates efficient dehydration and facilitates the process of rehydration (Sasmitaloka et al. 2019).

\section{Rehydration time}

Rehydration time is defined as the minimum time required by the dehydrated sample to re-absorb water and acquire a homogenous texture. Porosity is one important factor that affects the rehydration ability of the sample. The product with a more porous structure takes lesser time for rehydration as pores facilitate water penetration (Sasmitaloka et al. 2019).

\section{Volume expansion}

Volume expansion is the increase in volume caused by the absorption of water during the process of rehydration. Porosity and water absorption both act synergistically and facilitate volume expansion. It is the ratio of the volume of the sample after rehydration to the volume of the sample before rehydration.

Volume expansion $=\frac{V_{1}}{V_{2}}$
Where $\mathrm{V}_{1}=$ Volume of the sample after rehydration; $\mathrm{V}_{2}=$ Volume of the sample before rehydration

Higher porosity and more water penetration correspond to high volume expansion on rehydration (Sasmitaloka et al. 2019).

\section{Rehydration ratio}

The rehydration ratio is the ratio of the weight of the rehydrated sample to the weight of the sample after drying. It is a key quality aspect of dehydrated foods. The high value of the rehydration ratio indicates good quality of the dried product because the pores allow water to re-enter the cells more adequately.

Rehydration ratio $=\frac{W_{1}}{W_{2}}$

Where $\mathrm{W}_{1}=$ Weight of the sample after rehydration; $\mathrm{W}_{2}=$ Weight of the sample after drying

\section{Texture analysis}

Textural parameters of a product like hardness, springiness, chewiness, gumminess and cohesiveness were analyzed using a texture analyzer (TA.XT plus texture profile analyzer, Stable Micro Systems,UK). The rehydrated carrot shreds samples were first brought to room temperature and then analyzed for various textural parameters using back extrusion rig with a $35 \mathrm{~mm}$ disc with pre-test and test speed of $2 \mathrm{~mm} / \mathrm{sec}$. For ready-to-cook carrot halwa samples $1 \mathrm{~cm}$ of cube was cut from the central portion of the RTC halwa cake and analyzed for textural parameters using an $80 \mathrm{~mm}$ diameter cylindrical plunger at a crosshead speed of $50 \mathrm{~mm} / \mathrm{min}$ at $90^{\circ}$ of compression and the time gap between the two compressions varied between 6 and $7 \mathrm{sec}$. The trigger force was $5 \mathrm{~g}$ with the post-test speed of $5 \mathrm{~mm} / \mathrm{sec}$. Hardness, cohesiveness, springiness, gumminess, and chewiness, were calculated from the texture profile analysis as described by Bourne (1978).

\section{Khoa powder making}

The process for khoa powder making has been described in Figure 2.

\section{Experimental design}

The different variation in the ingredients level has been shown in Table 2. Optimization of ready to cook carrot halwa was done based on sensory evaluation, textural attributes, and color analysis.

\section{Sensory evaluation}

The carrot halwa samples were subjected to sensory evaluation using a 9- point hedonic scale. The sensory evaluation was 


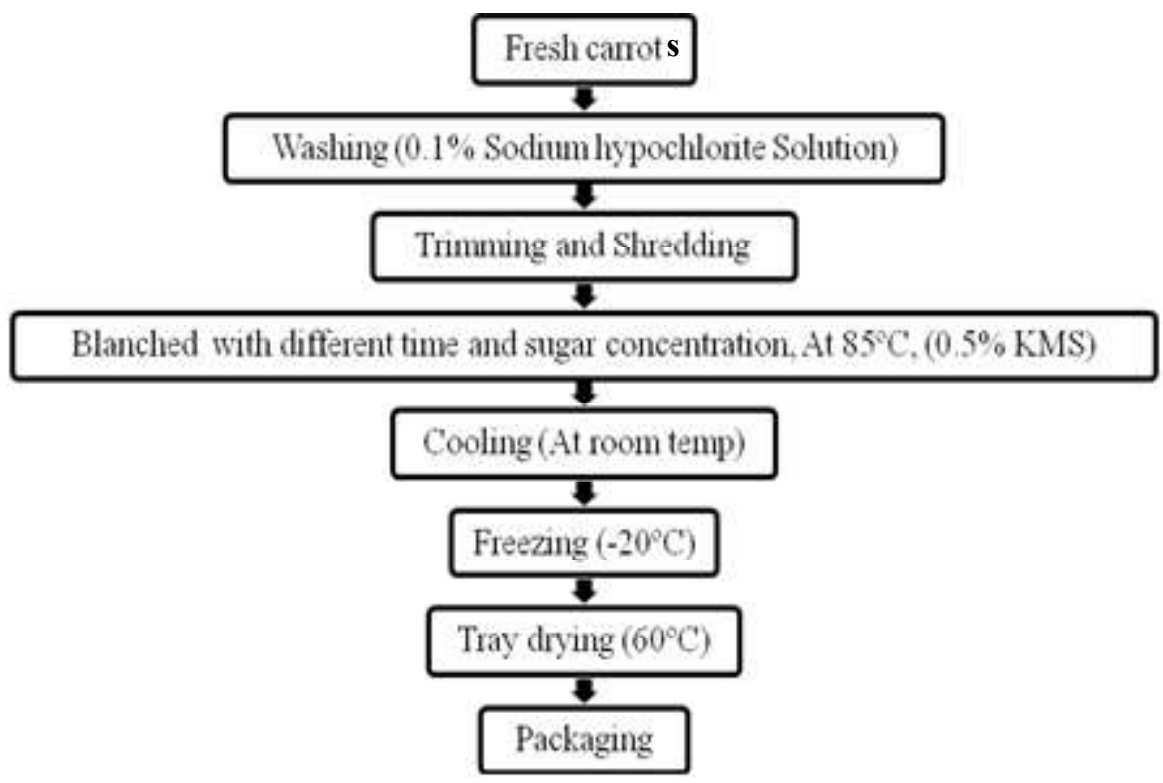

Fig. 1 Flowchart for the blanching and drying of carrot shreds

performed by a panel of 10 semi-trained judges (aged 25-35 years) from the Department of Dairy Science and Technology, Institute of Agricultural Sciences, Banaras Hindu University, Varanasi, India.The samples were served in odorless plastic trays. Water was used for mouth rinsing between the evaluations of two consecutive samples. All the analyses were performed in triplicate. The sensory evaluation was carried out at $25^{\circ} \mathrm{C}$ and $60 \%$ relative humidity (Ranganna, 2001). The sensory parameters that were studied include color, body and texture, flavor, and overall acceptability. The 9-point hedonic rating scale was arranged such that: Like extremely-9, Like very much-8, Like moderately-7, Like slightly-6, Neither like nor dislike-5, Dislike slightly-4, Dislike moderately-3, Dislike very much-2, Dislike extremely-1 (Amerine et al. 1965).

\section{Hunter color estimation}

The color coordinates $L^{*}, a^{*}, b^{*}$ ( $L^{*}$-lightness/darkness, a*redness/green, $b^{*}$ - yellowness/blue) were measured using D-65 illuminant, with a spectral range of 400-700nm and a spectral resolution of 10nm (color flex, CFLX-45-2, Hunter lab, Reston, USA). The photosensor was standardized using standard black and white color tiles before the analysis and the sample color values were read and recorded using Easy match QC software (Hunter Lab Reston, USA). The values of the sample color were taken at different intervals and were measured. The samples were tested under illuminate $\mathrm{C}$, view angle $2^{\circ}$, fast speed with slit width $2.0 \mathrm{~nm}$ following calibration with black and white standard tiles, samples of known weight and thickness were placed into a standard glass container and read an opponent color scales L, $a^{*}$ and $b^{*}$ were measured. The Hunter L, a, b color space is a three-dimensional rectangular color space based on the opponent color theory.L*(Lightness) axis indicates Lightness vs darkness, where a low number (0-50) indicates the dark and high number
(51-100) indicates light. $a^{*}$ indicates a red-green axis where a positive number indicates red and a negative number indicates green. $b^{*}$ indicates blue to the yellow axis where positive values are yellow; negative values are blue and 0 is neutral.

\section{Proximate analysis of the optimized product}

Proximate analysis of the optimized product was carried out for various parameters such as $\%$ protein, $\%$ fat, $\%$ ash, $\%$ moisture, and reducing sugar content as per the method prescribed by AOAC (2000).

\section{Statistical analysis}

All the experiments were performed in triplicate. The data of the analysis were pooled and the mean and standard deviation were calculated using MS excel software. Experiments were laid out in a completely randomized block design with three replications. Data on hardness, springiness, cohesiveness, gumminess, chewiness, density, rehydration time, rehydration ratio, and volume expansion were subjected to an analysis of variance (one way ANOVA). The difference at $\mathrm{p}<0.05$ was considered significant. For the computation of data, a software application program like Microsoft excel was used.

\section{Results and Discussion}

\section{Optimization of cooking properties of the blanched dried carrots shreds}

The data about the cooking properties of the blanched dried carrot shreds were presented in Table 1. The physicochemical properties like density, rehydration time, rehydration ratio, and volume expansion were calculated for the differently treated dried 


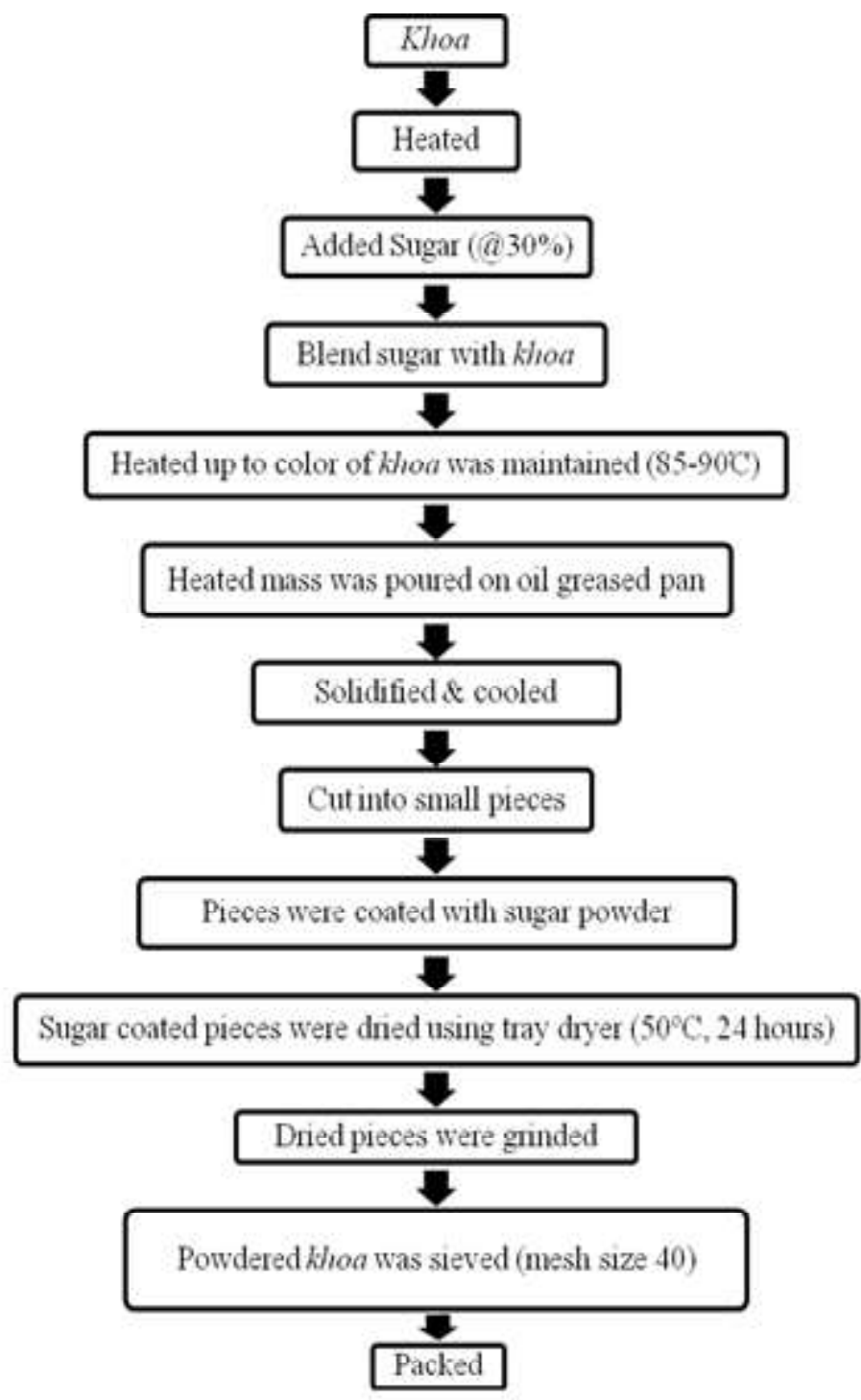

Fig. 2 Flowchart for the preparation of khoa powder

carrot shreds. The rehydration time in sec varies from 29.2 to 32.7 sec. There was no significant difference in the rehydration time in samples $T_{1}, T_{2}$, and $T_{3}$. But there was a significant difference in rehydration time of the treatment $T_{6}$. This could be because of the more blanching time and sugar concentration of the solution used for the blanching of the shredded carrots. The rehydration ratio tells about the amount of water uptake of the dried products. The maximum and minimum value for the rehydration ratio of the differently treated samples was 5.74 and 6.93. There was no significant difference between $\mathrm{T}_{1}, \mathrm{~T}_{2}, \mathrm{~T}_{3}$, and also in between $\mathrm{T}_{5}$, $\mathrm{T}_{6}$. But there was a significant difference between $\mathrm{T}_{1}, \mathrm{~T}_{4}$, and $\mathrm{T}_{6}$. This could be because of the difference in the blanching time of the different samples. Blanching leads to the oozing out of some of the constituents of the food products depending on the extent of treatment time and results in a difference in rehydration ratio. Higher rehydration ratio refers to better rehydration due to efficient moisture penetration in the dried sample. In a study, the effect of different drying temperatures on the quality of dehydrated carrot shreds was studied and showed that the rehydration ratio varies from 5.8 to 10.0 when subjected to different temperatures and time intervals (Qurtulanea et al. 2015).Volume expansion is another important parameter that deals with the tendency of the dried matter to change its shape, size, and volume when boiled in hot water. The maximum and minimum value of the volume expansion is 2.30 and 1.30. There was no significant difference between volume expansion of $\mathrm{T}_{1}, \mathrm{~T}_{2}, \mathrm{~T}_{3}$, and $\mathrm{T}_{4}, \mathrm{~T}_{6}$. But there was a significant difference between $\mathrm{T}_{3}, \mathrm{~T}_{5}$, and $\mathrm{T}_{6}$. This could be because of the variation in blanching time, drying temp, drying time, and the final moisture content of the dried products that greatly affect the structure, porosity, and water-absorbing capacity of dried samples. Based on these parameters, $T_{3}$ was found to be most effective treatment that gives moderate values 
Ingredients ( Dried carrot shreds, khoa powder, sugar, cardamom)

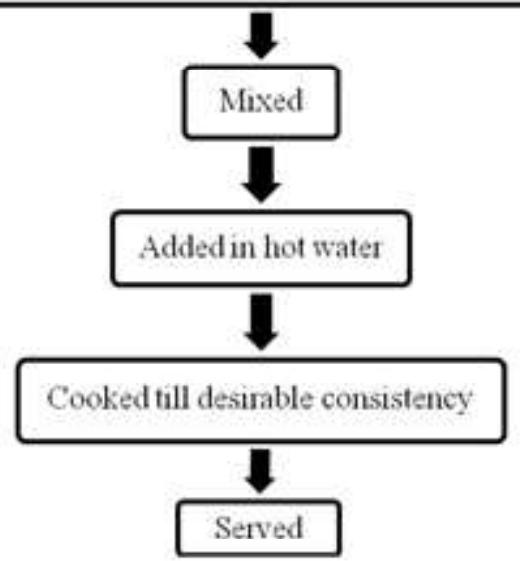

Fig. 3 Flowchart for the preparation of RTC carrot halwa

Table 1 Effect of blanching time and sugar concentration on cooking properties of dried carrot shreds

\begin{tabular}{|c|c|c|c|c|c|c|c|}
\hline Sample & $\begin{array}{l}\text { Blanching } \\
\text { Time (min) }\end{array}$ & $\begin{array}{l}\text { Sugar } \\
\text { Concentration }\end{array}$ & $\begin{array}{l}\text { KMS } \\
(\%)\end{array}$ & $\begin{array}{l}\text { Bulk } \\
\text { Density }\end{array}$ & $\begin{array}{l}\text { Rehydration } \\
\text { Time (Sec) }\end{array}$ & $\begin{array}{l}\text { Rehydration } \\
\text { Ratio }\end{array}$ & $\begin{array}{c}\text { Volume } \\
\text { Expansion }\end{array}$ \\
\hline$\overline{\mathrm{T}_{1}}$ & 2 & 8 & 0.5 & $0.61 \pm 0.02^{\mathrm{c}}$ & $29.5 \pm 5.23^{a}$ & $5.74 \pm 0.56^{\mathrm{a}}$ & $2.30 \pm 0.23^{\mathrm{c}}$ \\
\hline $\mathrm{T}_{2}$ & 5 & 8 & 0.5 & $0.38 \pm 0.06^{\mathrm{b}}$ & $29.9 \pm 2.19^{\mathrm{a}}$ & $5.86 \pm 0.63^{\mathrm{a}}$ & $2.21 \pm 0.36^{c}$ \\
\hline $\mathrm{T}_{4}$ & 2 & 12 & 0.5 & $0.22 \pm 0.03^{\mathrm{a}}$ & $30.6 \pm 2.36^{\mathrm{b}}$ & $6.22 \pm 1.23^{\mathrm{b}}$ & $1.60 \pm 0.29^{\mathrm{b}}$ \\
\hline $\mathrm{T}_{5}$ & 5 & 12 & 0.5 & $0.21 \pm 0.06^{\mathrm{a}}$ & $30.5 \pm 3.12^{b}$ & $6.79 \pm 0.83^{\mathrm{c}}$ & $1.30 \pm 0.39^{\mathrm{a}}$ \\
\hline
\end{tabular}

Values are mean \pm standard deviation, $n=3$, Values with different superscript letters in column indicate a significant difference $(\mathrm{p}<0.05)$.

Table 2 Experimental design with different level of ingredients and its effects on the color of ready-to-cook carrot halwa

\begin{tabular}{llllllll}
\hline Sample & Carrot $(\mathrm{g})$ & $\begin{array}{l}\text { Khoa } \\
\text { Powder }(\mathrm{g})\end{array}$ & $\begin{array}{l}\text { Sugar } \\
(\mathrm{g})\end{array}$ & $\begin{array}{l}\text { Cardamom } \\
(\mathrm{g})\end{array}$ & $\begin{array}{l}\mathrm{L}^{*} \\
\text { (Lightness) }\end{array}$ & $\begin{array}{l}\mathrm{a}^{*}(\text { Red- } \\
\text { green) }\end{array}$ & $\begin{array}{l}\mathrm{b}^{*}(\mathrm{Blue}- \\
\text { yellow) }\end{array}$ \\
\hline $\mathrm{H}_{1}$ & 15 & 20 & 12.8 & 1 & $31.56 \pm 0.34^{\mathrm{a}}$ & $19.89 \pm 0.14^{\mathrm{c}}$ & $13.92 \pm 0.02^{\mathrm{a}}$ \\
$\mathrm{H}_{2}$ & 15 & 20 & 28.2 & 1 & $32.28 \pm 0.26^{\mathrm{b}}$ & $20.17 \pm 0.17^{\mathrm{d}}$ & $14.33 \pm 0.14^{\mathrm{b}}$ \\
$\mathrm{H}_{3}$ & 15 & 25 & 19.2 & 1 & $32.98 \pm 1.66^{\mathrm{b}}$ & $19.25 \pm 0.57^{\mathrm{c}}$ & $14.14 \pm 0.15^{\mathrm{b}}$ \\
$\mathrm{H}_{4}$ & 15 & 25 & 28.8 & 1 & $33.27 \pm 1.85^{\mathrm{c}}$ & $19.21 \pm 0.81^{\mathrm{c}}$ & $14.11 \pm 0.17^{\mathrm{b}}$ \\
$\mathrm{H}_{5}$ & 15 & 30 & 19.6 & 1 & $33.96 \pm 0.19^{\mathrm{c}}$ & $19.11 \pm 0.02^{\mathrm{c}}$ & $13.99 \pm 0.02^{\mathrm{a}}$ \\
$\mathrm{H}_{6}$ & 15 & 30 & 29.4 & 1 & $34.22 \pm 0.27^{\mathrm{d}}$ & $18.02 \pm 0.23^{\mathrm{b}}$ & $14.75 \pm 0.22^{\mathrm{b}}$ \\
$\mathrm{H}_{7}$ & 15 & 40 & 18.6 & 1 & $35.87 \pm 0.05^{\mathrm{e}}$ & $17.43 \pm 0.22^{\mathrm{a}}$ & $13.95 \pm 0.26^{\mathrm{a}}$ \\
\hline
\end{tabular}

Values are mean \pm standard deviation, $n=3$, Values with different superscript letters in column indicate a significant difference ( $p<0.05$ ).

of bulk density, rehydration ratio and volume expansion relating to desirable porous texture of shreds with lowest rehydration time.

\section{Texture profile analysis of carrot shreds}

The data about the textural properties of the blanched dried carrot shreds were presented in Table 3. Hardness, springiness, cohesiveness, gumminess, and chewiness were analyzed using force-time textural curve. Hardness $(\mathrm{N})$ is the force necessary to attain a given deformation of the material or it is the force required to bite through the sample with molars. Rehydrated carrot shreds with a low value for hardness means soft and smooth in texture and vice-versa. Cohesiveness is related to work required to overcome the internal bonding or maximum degree to which the sample holds together in a mass while chewing. Springiness is described as the rate at which a deformed material recovers to its original form under formed conditions after the deforming force was removed. Rehydrated carrot with higher springiness possesses higher elasticity. The rehydrated carrot with higher 
chewiness was stiffer and harder to eat. The middle portion of the rehydrated carrot was analyzed for textural parameters because it had a homogeneous texture. Textural parameters were influenced by parameters like cooking time, blanching time, drying temp, drying time, and the final moisture in the dried products. Out of all the differently treated samples, $\mathrm{T}_{3}$ has the minimum hardness and sample $T_{1}$ has the maximum hardness followed by $\mathrm{T}_{5}$. But there is no significant difference in the hardness other samples such as $\mathrm{T}_{2}, \mathrm{~T}_{4}$, and $\mathrm{T}_{6}$.

The average springiness of the rehydrated carrot was found to be around 8.0 to 8.4 . $\mathrm{T}_{2}$ and $\mathrm{T}_{4}$ show the maximum and minimum springiness respectively which is $9.34 \pm 0.32$ and $6.95 \pm 0.64$. The highest value for cohesiveness was noticed in $\mathrm{T}_{1}(0.63 \pm 0.03)$ and the least values in other $T_{2}$ and $T_{3}$. Gumminess i.e. force required to disintegrate a semisolid sample for swallowing. Again $\mathrm{T}_{4}$ showed the highest value $(8.72 \pm 1.62 \mathrm{~N})$ and least for $\mathrm{T}_{6}(5.84 \pm 1.69$ $\mathrm{N}$ ). Based on these results, $\mathrm{T}_{3}$ was selected as it gives moderate values for hardness, springiness, gumminess, cohesiveness and chewiness.

\section{Sensory evaluation of carrot halwa}

The sensory quality of the carrot halwa prepared using different levels of ingredients was evaluated by a panel of judges. The data about the sensory properties of the ready-to-cook carrot halwa were presented in Table 4.

The sensory score for color and appearance, body and texture, flavor, and overall acceptability for all the seven variants was found to be significantly different from each other $(\mathrm{p}<0.05)$. The maximum sensory score for color and appearance, body and texture, flavor, and overall acceptability was found for variant $\mathrm{H}_{4}$ as shown in Table 4. The factors that mainly contributed to the sensory parameters of the carrot halwa were the amount of carrot shreds and khoa powder. The amount of carrot shreds and khoa powder in the premix contributed to brighter color and more acceptable body and texture. The addition of khoa powder affected the flavor of the carrot halwa. In the case of overall acceptability, all the samples had been given average scores that correspond to descriptors "like moderately to like very much".

\section{Color analysis of carrot halwa}

The color parameters for developed ready-to-cook carrot halwa were studied using Color flex hunter colorimeter. The data about the color parameters for ready-to-cook carrot halwa was presented in Table 2 . The variation in $\mathrm{L}^{*}$ value was basically because of the different amount of khoa powder and sugar used for the preparation of the carrot halwa. The maximum value of $\mathrm{L}$ is $35.87 \pm 0.05$ and a minimum value of $L^{*}$ is $31.56 \pm 0.34$. The value of $\mathrm{L}^{*}$ was maximum in the case of $\mathrm{H}_{7}$ which could be because of the highest amount of khoa powder used in the preparation. There was a gradual increase in the lightness value from $\mathrm{H}_{1}$ to $\mathrm{H}_{7}$ which could be because of the increasing amount of khoa powder and sugar. There was a significant difference in $\mathrm{L}$ value between $\mathrm{H}_{1}$ and $\mathrm{H}_{7}$. A positive $\mathrm{a}$ * value indicates the intensity of the red color of the product while the negative value indicates the green

Table 3 Texture profile snalysis of the differently treated dried carrot shreds

\begin{tabular}{llllll}
\hline Treatment & Hardness $(N)$ & Springiness & Cohesiveness & Gumminess & Chewiness \\
\hline $\mathrm{T}_{1}$ & $82 \pm 2.36^{\mathrm{d}}$ & $9.92 \pm 0.73^{\mathrm{d}}$ & $0.633 \pm 0.03^{\mathrm{a}}$ & $6.13 \pm 1.02^{\mathrm{b}}$ & $5.98 \pm 0.65^{\mathrm{a}}$ \\
$\mathrm{T}_{2}$ & $65 \pm 3.25^{\mathrm{b}}$ & $9.34 \pm 0.32^{\mathrm{d}}$ & $0.383 \pm 0.06^{\mathrm{b}}$ & $7.62 \pm 0.46^{\mathrm{c}}$ & $7.92 \pm 0.46^{\mathrm{c}}$ \\
$\mathrm{T}_{3}$ & $42 \pm 2.36^{\mathrm{a}}$ & $7.63 \pm 0.36^{\mathrm{b}}$ & $0.376 \pm 0.05^{\mathrm{b}}$ & $6.88 \pm 0.96^{\mathrm{b}}$ & $5.05 \pm 0.96^{\mathrm{a}}$ \\
$\mathrm{T}_{4}$ & $61 \pm 1.36 \mathrm{~b}$ & $6.95 \pm 0.64^{\mathrm{a}}$ & $0.559 \pm 0.03^{\mathrm{c}}$ & $8.72 \pm 1.62^{\mathrm{d}}$ & $6.05 \pm 1.36^{\mathrm{b}}$ \\
$\mathrm{T}_{5}$ & $76 \pm 3.36^{\mathrm{c}}$ & $8.28 \pm 0.25^{\mathrm{c}}$ & $0.514 \pm 0.09^{\mathrm{c}}$ & $6.72 \pm 1.63^{\mathrm{b}}$ & $5.50 \pm 1.46^{\mathrm{a}}$ \\
$\mathrm{T}_{6}$ & $65 \pm 1.65^{\mathrm{b}}$ & $7.15 \pm 0.35^{\mathrm{b}}$ & $0.520 \pm 0.05^{\mathrm{c}}$ & $5.84 \pm 1.69^{\mathrm{a}}$ & $6.25 \pm 1.82^{\mathrm{b}}$ \\
\hline
\end{tabular}

Values are mean \pm standard deviation, $n=3$, Values with different superscript letters in column indicate a significant difference $(\mathrm{p}<0.05)$.

Table 4 Sensory evaluation of ready-to-cook carrot halwa

\begin{tabular}{llllr}
\hline Sample & Color \& Appearance & Body and Texture & Flavor & Overall acceptance \\
\hline $\mathrm{H}_{1}$ & $6.75 \pm 0.46^{\mathrm{b}}$ & $6.75 \pm 0.65^{\mathrm{a}}$ & $7.42 \pm 0.56^{\mathrm{b}}$ & $6.89 \pm 0.70^{\mathrm{a}}$ \\
$\mathrm{H}_{2}$ & $7.64 \pm 0.94^{\mathrm{c}}$ & $7.21 \pm 0.69^{\mathrm{b}}$ & $7.07 \pm 0.73^{\mathrm{b}}$ & $7.38 \pm 0.78^{\mathrm{b}}$ \\
$\mathrm{H}_{3}$ & $7.28 \pm 0.75^{\mathrm{c}}$ & $7.42 \pm 0.53^{\mathrm{b}}$ & $7.21 \pm 0.81^{\mathrm{b}}$ & $7.35 \pm 0.74^{\mathrm{b}}$ \\
$\mathrm{H}_{4}$ & $7.83 \pm 0.51^{\mathrm{c}}$ & $8.33 \pm 0.51^{\mathrm{c}}$ & $7.93 \pm 0.98^{\mathrm{b}}$ & $7.83 \pm 0.54^{\mathrm{b}}$ \\
$\mathrm{H}_{5}$ & $6.91 \pm 0.81^{\mathrm{b}}$ & $6.75 \pm 0.61^{\mathrm{a}}$ & $7.08 \pm 0.66^{\mathrm{b}}$ & $6.91 \pm 0.64^{\mathrm{a}}$ \\
$\mathrm{H}_{6}$ & $5.83 \pm 1.32^{\mathrm{a}}$ & $6.41 \pm 1.28^{\mathrm{a}}$ & $7.16 \pm 1.16^{\mathrm{b}}$ & $6.47 \pm 1.13^{\mathrm{a}}$ \\
$\mathrm{H}_{7}$ & $6.16 \pm 1.16^{\mathrm{b}}$ & $6.58 \pm 0.91^{\mathrm{a}}$ & $6.51 \pm 1.04^{\mathrm{a}}$ & $6.41 \pm 0.93^{\mathrm{a}}$ \\
\hline
\end{tabular}

Values are mean \pm standard deviation, $n=3$, Values with different superscript letters in column indicate a significant difference $(\mathrm{p}<0.05)$. 
Table 5 Textural profile analysis of ready-to-cook carrot halwa

\begin{tabular}{llllll}
\hline Treatment & Hardness $(\mathrm{N})$ & Springiness & Cohesiveness & Gumminess & Chewiness \\
\hline $\mathrm{H}_{1}$ & $2.11 \pm 0.36^{\mathrm{a}}$ & $0.57 \pm 0.03^{\mathrm{c}}$ & $0.65 \pm 0.02^{\mathrm{d}}$ & $1.14 \pm 0.23^{\mathrm{a}}$ & $2.07 \pm 0.83^{\mathrm{c}}$ \\
$\mathrm{H}_{2}$ & $4.22 \pm 0.63^{\mathrm{b}}$ & $0.95 \pm 0.03^{\mathrm{e}}$ & $0.39 \pm 0.03^{\mathrm{b}}$ & $3.32 \pm 0.13^{\mathrm{c}}$ & $3.14 \pm 0.73^{\mathrm{d}}$ \\
$\mathrm{H}_{3}$ & $4.02 \pm 1.02^{\mathrm{b}}$ & $0.99 \pm 0.06^{\mathrm{e}}$ & $0.43 \pm 0.03^{\mathrm{c}}$ & $2.56 \pm 0.16^{\mathrm{b}}$ & $2.54 \pm 0.62^{\mathrm{c}}$ \\
$\mathrm{H}_{4}$ & $2.85 \pm 1.23^{\mathrm{a}}$ & $0.68 \pm 0.05^{\mathrm{d}}$ & $0.37 \pm 0.06^{\mathrm{b}}$ & $1.07 \pm 0.18^{\mathrm{a}}$ & $0.73 \pm 0.65^{\mathrm{a}}$ \\
$\mathrm{H}_{5}$ & $4.50 \pm 1.63^{\mathrm{b}}$ & $0.51 \pm 0.08^{\mathrm{c}}$ & $0.21 \pm 0.05^{\mathrm{a}}$ & $2.85 \pm 0.21^{\mathrm{b}}$ & $3.27 \pm 0.68^{\mathrm{d}}$ \\
$\mathrm{H}_{6}$ & $5.32 \pm 1.24^{\mathrm{c}}$ & $0.42 \pm 0.05^{\mathrm{b}}$ & $0.19 \pm 0.05^{\mathrm{a}}$ & $1.28 \pm 0.25^{\mathrm{a}}$ & $1.53 \pm 0.52^{\mathrm{b}}$ \\
$\mathrm{H}_{7}$ & $4.26 \pm 0.35^{\mathrm{b}}$ & $0.33 \pm 0.02^{\mathrm{a}}$ & $0.15 \pm 0.03^{\mathrm{a}}$ & $1.04 \pm 0.19^{\mathrm{a}}$ & $1.35 \pm 0.58^{\mathrm{b}}$ \\
\hline
\end{tabular}

Values are mean \pm standard deviation, $n=3$, Values with different superscript letters in column indicate a significant difference $(\mathrm{p}<0.05)$.

color of the product. Higher the magnitude of the value greater will be the intensity of the particular color. The value of $a^{*}$ for the carrot halwa varies from 17.43 to 20.17 . For $\mathrm{H}_{2}$ the a* value wasmore as compared to another sample this could be because of the less amount of khoa powder used in the preparation. In other formulation, the amount of khoa powder was more which would have masked the red color of the carrot. A positive value of $b^{*}$ indicates the intensity of the yellow color in the product while the negative value indicates the magnitude of the blue color of the halwa. In the product, the positive value of $b^{*}$ is because of the carrot but the color intensity is very less, and not much significant difference was observed amongst the different samples. The highest value of $b *$ is $14.75 \pm 0.22$ and the minimum value is $13.92 \pm 0.02$.

\section{Texture profile analysis of ready-to-cook carrot halwa}

Texture analyses of seven samples of RTC halwa were performed and various parameters were measured such as hardness, cohesiveness, springiness, gumminess, and chewiness using force-time textural curve. The RTC halwa variant with a low value for hardness means soft and smooth in texture and vice-versa. RTC halwa with higher springiness possesses higher elasticity. Therefore, RTC halwa with higher chewiness is stiffer and harder to eat. The middle portion of the RTC halwa was analyzed for textural parameters because it had a homogeneous texture. Textural parameters were influenced by the type of carrots used in the base material of the halwa. From table 5 it was observed that sample $\mathrm{H}_{4}$ exhibited the least hardness whereas maximum hardness was observed in the case of $\mathrm{H}_{6}$. The highest gumminess and chewiness were found in sample $\mathrm{H}_{2}$. Cohesiveness was found to be highest in sample $\mathrm{H}_{1}$. From the table, it can be concluded that sample $\mathrm{H}_{4}$ was found to have the least values for chewiness and hardness and moderate values for springiness, cohesiveness, and gumminess. On the following basis, it can be concluded that treatment $\mathrm{H}_{4}$ can be adoptedreasonably for further processing.

\section{Proximate analysis of ready-to-cook carrot halwa}

Proximate composition of ready-to-cook carrot halwa premix was found to be $7.41 \%$ protein, $5.84 \%$ fat, $3.11 \%$ ash, $67 \%$ carbohydrate, and $13.35 \%$ moisture.

\section{Conclusions}

Ready-to-cook carrot halwa that require minimal preparation time was successfully developed keeping in mind the consumers escalating demand for instant foods. $\mathrm{T}_{3}$ was optimized as the best treatment for dehydration of carrot shreds that offers desirable porous structure to the shreds. Further, the variant $\mathrm{H}_{4}$ stood out to be best amongst all the variants of carrot halwa based on sensorial, textual, and color parameters. The developed ready-tocook carrot halwa takes 4-5min to prepare with sensory, textural, and color characteristics similar to the traditionally prepared product. The overall acceptability of optimized product was $7.83 \pm 0.54$. The developed RTC carrot halwa can be relished at any time with minimal preparation and provide an effective solution to constraints related to seasonal availability of raw materials.

\section{References}

Amerine MA, Pangborn RM, Roessler EB (1965) Principles of sensory evaluation of foods. Academic Press, London.

AOAC (2000) Official Methods of Analysis. Association of Official Analytical Chemists, Gaithersburg, Maryland

Bourne MC (1978) Texture profile analysis. J Food Sci Technol 32: 62-67

Mansoor GZ, Khursheed K, Jairajpuri DS (2013) Preparation, processing, and packaging of pre-mix for the production of carrot dessert. IOSR J Environ Sci Toxicol Food Technol 3: 38-42

Mathpal R, Kulshrestha K, Kushwaha A (2017) Quality and safety of market vs home made carrot halwa: designing a safe process. Int $\mathrm{J}$ Food Sci Technol 7: 1-12

Munjal N, Noida G (2019) Consumers' Expectations towards ready-tocook food-an empirical study of Delhi/NCR. Recent Trends in Decision Sciences and their Implications for Business 99-110

Qurtulanea, Zargara I A, Mehraj-ud-udinb S, Bisatic IA, Kumar A (2015) Effect of different drying temperature on the quality of dehydrated carrot shreds. Ecol Environ Conserv 21: 1317-1320

Ranganna S (2001) Handbook of analysis of fruits and vegetable products. $2^{\text {nd }}$ ed., Tata Mc-Graw-Hill Pub. Com. Ltd., New Delhi

Sasmitaloka KS, Widowati S, Sukasih E (2019) Effect of freezing temperature and duration on physicochemical characteristics of instant rice. In IOP Conference Series: Earth and Environ Sci 309: $1-8$ 